The LIFE Laser Design in Context: A Comparison to the State-of-the-Art

R. J. Deri, A. J. Bayramian, A. C. Erlandson

April 1, 2011 
This document was prepared as an account of work sponsored by an agency of the United States government. Neither the United States government nor Lawrence Livermore National Security, LLC, nor any of their employees makes any warranty, expressed or implied, or assumes any legal liability or responsibility for the accuracy, completeness, or usefulness of any information, apparatus, product, or process disclosed, or represents that its use would not infringe privately owned rights. Reference herein to any specific commercial product, process, or service by trade name, trademark, manufacturer, or otherwise does not necessarily constitute or imply its endorsement, recommendation, or favoring by the United States government or Lawrence Livermore National Security, LLC. The views and opinions of authors expressed herein do not necessarily state or reflect those of the United States government or Lawrence Livermore National Security, LLC, and shall not be used for advertising or product endorsement purposes.

This work performed under the auspices of the U.S. Department of Energy by Lawrence Livermore National Laboratory under Contract DE-AC52-07NA27344. 


\title{
The LIFE Laser Design in Context: A Comparison to the State-of-the-Art
}

\author{
R. Deri, A. Bayramian, and A. Erlandson \\ March 18, 2011
}

The current point design for the LIFE laser[1] leverages decades of solid-state laser development in order to achieve the performance and attributes required for inertial fusion energy. This document provides a brief comparison of the LIFE laser point design to other state-of-the-art solid-state lasers.

Table I compares the attributes of the current LIFE laser point design to other systems. The state-of-the-art for single-shot performance at fusion-relevant beamline energies is exemplified by performance observed on the National Ignition Facility.[2,3] The state-of-the-art for high average power is exemplified by the Northrup Grumman JHPSSL laser.[4]

Several items in Table I deal with the laser efficiency; a more detailed discussion of efficiency can be found in Ref. [5]. The electrical-to-optical efficiency of the LIFE design exceeds that of Ref. [4] due to the availability of higher efficiency laser diode pumps ( $70 \%$ vs. $\sim 50 \%$ used in [4]). LIFE diode pumps are discussed in greater detail in Ref. [6]. The "beam steering" state of the art is represented by the deflection device that will be used in the LIFE laser, not a laser system.[10].

Table I: Comparison of the LIFE Laser Point Design to State-of-the-Art Solid State Lasers

\begin{tabular}{|c|c|c|c|}
\hline Item & LIFE & State of the Art & Reference \\
\hline Beamline Power (kW at $1 \omega)$ & 130 & 105 & Marmo et al. [4] \\
\hline $\begin{array}{l}\text { Beamline Power per Aperture } \\
\left(\mathrm{kW} / \mathrm{cm}^{2} \text { at } 1 \omega\right)\end{array}$ & 235 & 250 & Boley et al. [7] \\
\hline $\begin{array}{l}\text { Energy per pulse, } \\
1 \omega / 3 \omega \text { (kJ/ beamline) }\end{array}$ & $8.1 / 5.7$ & $22 / 10.6$ & Haynam et al. [3] \\
\hline Operating Fluence $\left(\mathrm{J} / \mathrm{cm}^{2}, 1 \omega / 3 \omega\right)$ & $15.6 / 5.7$ & $16 / 12$ & Haynam et al. [3] \\
\hline Aperture size (cm square $\left.1_{\omega}\right)$ & 25 & 40 & Haynam et al. [2] \\
\hline $\begin{array}{l}\text { Beam quality } \\
\text { (x diffraction limited) }\end{array}$ & 5 & $5,1.7$ & $\begin{array}{l}\text { Haynam et al. [2], } \\
\text { Marmo et al. [4] }\end{array}$ \\
\hline Bandwidth (GHz) & 180 & 1000 & Regan et al. [12] \\
\hline $1 \omega$ efficiency optical to optical & $39 \%$ & $50 \%$ & Feugnet et al. [8] \\
\hline $\begin{array}{l}\text { Diode efficiency } \\
\text { (pump source) }\end{array}$ & $72 \%$ & $73 \%$ & Kanskar et al. [9] \\
\hline $1_{\omega}$ efficiency electrical to optical & $25 \%$ & $20 \%, 19 \%$ & $\begin{array}{c}\text { Trumpf, [10] } \\
\text { Marmo et al. [4] }\end{array}$ \\
\hline Frequency conversion efficiency & $75 \%$ & $84 \%$ & Haynam et al. [2] \\
\hline Fast beam steering (mrad $/ \mu \mathrm{sec})$ & $26 / 10$ & $150 / 10$ & Nakamura et al.[11] \\
\hline
\end{tabular}


Inspection of Table I shows that most LIFE laser attributes have already been experimentally demonstrated. The two cases where the LIFE design is somewhat better than prior experimental work do not involve the development of new concepts: beamline power is increased simply by increasing aperture (as demonstrated by the power/aperture comparison in Table I), and efficiency increases are achieved by employing state-of-the-art diode pumps.

In conclusion, the attributes anticipated for the LIFE laser are consistent with the demonstrated performance of existing solid-state lasers.

\section{REFERENCES}

[1] A.J. Bayramian et al., "Compact, Efficient laser systems required for Laser Inertial Fusion Energy," 19th Topical Mtg Fusion Energy (ANS, Las Vegas, NV; November 2010), Paper T3OS-12-1; to appear in Fusion Sci. Technol. (2011).

[2] C.A. Haynam et al., "National Ignition Facility laser performance status," Appl. Opt. 46, 3276 (2007)

[3] C.A. Haynam, R. A. Sacks, E. I. Moses, K. Manes, S. Haan, and M. L. Spaeth, "Response to comment on "The National Ignition Facility laser performance status," Appl. Opt, 47, 13841386, (2008).

[4] J. Marmo, H. Injeyan, H. Komine, S. McNaught, J. Machan, J. Sollee, "Joint High Power Solid State Laser program advancements at Northrop Grumman,” Proc. SPIE 7195, 719507-1-6, (2009).

[5] R.J. Deri, A.C. Erlandson, and A.J. Bayramian, "Efficiency of the LIFE Laser," LLNL-TR469571 (Lawrence Livermore National Laboratory, February 2011).

[6] R.J. Deri et al., "Semiconductor Laser Diode Pumps for Inertial Fusion Energy Lasers," LLNL-TR-465931 (Lawrence Livermore National Laboratory, 2011).

[7] C.D. Boley, K.P. Cutter, et al., "Interaction of a high-power laser beam with metal sheets", $J$. Appl. Phys.107, 043106 2010.

[8] G. Feugnet et al., "High-efficiency TEM00 Nd:YVO4 laser longitudinally pumped by a high-power array," Opt. Lett. 20,157 (1995).

[9] M. Kanskar et al., " $73 \% \mathrm{CW}$ power conversion efficiency at 50W from $970 \mathrm{~nm}$ diode laser bars," Electron. Lett. 41, 245 (2005).

[10] Trumpf, "TruDisk 16002 Datasheet," http://www.us.trumpf.com/.

[11] K. Nakamura, "A novel high-speed electro-optic beam scanner based on KTN crystals", $J$. Appl. Phys.104, 013105 (2008).

[12] S.P. Regan, J.A. Marozas et al., "Performance of 1-THz-bandwidth, two-dimensional smoothing by spectral dispersion and polarization smoothing of high-power, solid-state laser beams," J. Opt. Soc. Am. B 22, 998-1002 (2005). 